DiRECTEUR DE LA PUBLICATION: Bruno David,

Président du Muséum national d'Histoire naturelle

RÉdACTEUR EN CHEF / EDITOR-IN-CHIEF: Didier Merle

ASSISTANTS DE RÉDACTION / AsSISTANT EDITORS: Emmanuel Côtez (geodiv@mnhn.fr); Anne Mabille

MISE EN PAGE / PAGE LAYOUT: Emmanuel Côtez

COMITÉ SCIENTIFIQUE / SCIENTIFIC BOARD:

Christine Argot (MNHN, Paris)

Beatrix Azanza (Museo Nacional de Ciencias Naturales, Madrid)

Raymond L. Bernor (Howard University, Washington DC)

Alain Blieck (USTL, Villeneuve d'Ascq)

Henning Blom (Uppsala University)

Jean Broutin (UPMC, Paris)

Gaël Clément (MNHN, Paris)

Ted Daeschler (Academy of Natural Sciences, Philadelphie)

Bruno David (MNHN, Paris)

Gregory D. Edgecombe (The Natural History Museum, Londres)

Ursula Göhlich (Natural History Museum Vienna)

Jin Meng (American Museum of Natural History, New York)

Brigitte Meyer-Berthaud (CIRAD, Montpellier)

Zhu Min (Chinese Academy of Sciences, Pékin)

Isabelle Rouget (UPMC, Paris)

Sevket Sen (MNHN, Paris)

Stanislav Štamberg (Museum of Eastern Bohemia, Hradec Králové)

Paul Taylor (The Natural History Museum, Londres)

COUVERTURE / COVER:

Réalisée à partir des Figures de l'article/created from Figures of the article.

Geodiversitas est indexé dans / Geodiversitas is indexed in:

- Science Citation Index Expanded (SciSearch ${ }^{\circledR}$ )

- ISI Alerting Services ${ }^{\circledR}$

- Current Contents ${ }^{\circledR}$ / Physical, Chemical, and Earth Sciences ${ }^{\circledR}$

- Scopus ${ }^{\circledR}$

Geodiversitas est distribué en version électronique par / Geodiversitas is distributed electronically by:

- BioOne ${ }^{\circledR}$ (http://www.bioone.org)

Les articles ainsi que les nouveautés nomenclaturales publiés dans Geodiversitas sont référencés par / Articles and nomenclatural novelties published in Geodiversitas are referenced by:

- ZooBank ${ }^{\circledR}$ (http://zoobank.org)

Geodiversitas est une revue en flux continu publiée par les Publications scientifiques du Muséum, Paris Geodiversitas is a fast track journal published by the Museum Science Press, Paris

Les Publications scientifiques du Muséum publient aussi / The Museum Science Press also publish: Adansonia, Zoosystema, Anthropozoologica, European Journal of Taxonomy, Naturae.

Diffusion - Publications scientifiques Muséum national d'Histoire naturelle

CP $41-57$ rue Cuvier F-75231 Paris cedex 05 (France)

Tél. : 33 (0)1 40794805 / Fax: 33 (0)1 40793840

diff.pub@mnhn.fr / http://sciencepress.mnhn.fr

(C) Publications scientifiques du Muséum national d'Histoire naturelle, Paris, 2018

ISSN (imprimé / print): 1280-9659/ ISSN (électronique / electronic): 1638-9395 


\title{
Previously unknown fossil platyrrhines (Primates) of Patagonia from the Tournouerr collection at the Muséum national d'Histoire naturelle, Paris
}

\author{
Nelson M. NOVO \\ Instituto Patagónico de Geología y Paleontología (IPGP), CONICET-CENPAT, \\ Boulevard Brown 2915, (9120) Puerto Madryn, Chubut (Argentina) \\ and Facultad de Ciencias Naturales, Sede Puerto Madryn, \\ Universidad Nacional de la Patagonia "San Juan Bosco", Puerto Madryn, Chubut (Argentina) \\ nelsonovo@gmail.com \\ Marcelo F. TEJEDOR \\ Instituto Patagónico de Geología y Paleontología (IPGP), CONICET-CENPAT, \\ Boulevard Brown 2915, (9120) Puerto Madryn, Chubut (Argentina) \\ and Gothenburg Global Biodiversity Centre, Box 461, SE 40530 Göteborg (Sweden) \\ and Facultad de Ciencias Naturales, Sede Trelew, \\ Universidad Nacional de la Patagonia "San Juan Bosco", Trelew, Chubut (Argentina) \\ tejedor@cenpat-conicet.gob.ar
}

Laureano R. GONZÁLEZ RUIZ Centro de Investigación Esquel de Montaña y Estepa Patagónicas (CIEMEP), CONICET-UNPSJB Roca 780, CP 9200, Esquel, Chubut (Argentina) and Facultad de Ciencias Naturales, Sede Esquel, Universidad Nacional de la Patagonia "San Juan Bosco". Esquel, Chubut (Argentina) Irgonzalezruiz@comahue-conicet.gob.ar

Submitted on 21 March 2018 | accepted on 2 June 2018 | published on 8 November 2018

urn:Isid:zoobank.org:pub:61939862-091E-44F6-8811-4A1C4709ACBB

Novo N. M., Tejedor M. F. \& González Ruiz L. R. 2018. - Previously unknown fossil platyrrhines (Primates) of Patagonia from the Tournouër collection at the Muséum national d'Histoire naturelle, Paris. Geodiversitas 40 (22): $529-535$. https://doi.org/10.5252/geodiversitas2018v40a22. http://geodiversitas.com/40/22

\section{ABSTRACT}

Three unpublished fossil primate specimens from Patagonia (Argentina) are reported here. They are part of the Tournouër collection housed at the Muséum national d'Histoire naturelle in Paris, France, and correspond to a partial mandible collected in 1902, and one upper deciduous premolar and one upper permanent molar collected in 1899. The partial mandible comes from the early Miocene sediments in the Coyle river area (Santa Cruz Province, Argentina), and is attributable to Homunculus patagonicus Ameghino, 1891. It adds to the several specimens assigned to Homunculus patagonicus that were collected since the times of the Ameghino brothers in the area, between the rivers Coyle and Gallegos. Two other dental specimens came from Colhue-Huapi (Chubut province, Argentina).

KEY WORDS

Fossil Platyrrhines,

Patagonia

Argentina,

Tournouër collection. Both are here assigned to Mazzonicebus almendrae Kay, 2010, the only known fossil primate in the early Miocene levels of Gran Barranca, in the Colhue-Huapi area. This contribution provides new morphological information concerning the mandible and dentition of Homunculus Ameghino, 1891, and the first evidence of the deciduous dentition of Mazzonicebus Kay, 2010. 


\section{MOTS CLÉS \\ Fossiles Platyrrines, \\ Patagonie, \\ Argentine,}

\section{RÉSUMÉ}

Spécimens non publiés de primates fossiles de Patagonie (Argentine) de la collection Tournouër du Muséum national d'Histoire naturelle, Paris.

Trois spécimens non publiés de primates fossiles de Patagonie (Argentine) sont étudiés ici. Ils font partie de la collection Tournouër conservée au Muséum national d'Histoire naturelle à Paris, France, et correspondent à une mandibule partielle recueillie en 1902, une prémolaire supérieure caduque et une molaire permanente supérieure recueillies en 1899. La mandibule partielle provient des sédiments du Miocène inférieur dans la région de la rivière Coyle (Province de Santa Cruz, Argentine), et est attribuable à Homunculus patagonicus Ameghino, 1891. Par ailleurs, entre les rivières Coyle et Gallegos, plusieurs spécimens attribués à Homunculus patagonicus ont été collectés depuis l'époque des frères Ameghino. Les deux autres spécimens dentaires proviennent de ColhueHuapi (Province de Chubut, Argentine), et sont ici assignés à Mazzonicebus almendrae Kay, 2010, l'unique primate fossile connu dans les niveaux du Miocène inférieur de Gran Barranca, région de Colhue-Huapi. Cette contribution fournit de nouvelles informations morphologiques sur la mandibule et la dentition de Homunculus Ameghino, 1891, et est la première preuve de dentition lactéale de Mazzonicebus Kay, 2010.

\section{INTRODUCTION}

The platyrrhine primates, or New World Monkeys (NWM) are a diverse group of mammals currently distributed in the Neotropical Region (Morrone 2006), but whose past populations expanded also into the Caribbean Greater Antilles and as far south as Patagonia (see Tejedor \& Novo 2017).

The platyrrhine fossil record is relatively diverse, but scarce in comparison with other mammals occurring at the same paleontological sites. A total of 33 extinct platyrrhine genera have been described thus far from Central and South America, as well as some Caribbean islands, and at least four extinct species of two living genera (Tejedor \& Novo 2017). The oldest records are from ?late Eocene of Santa Rosa, Peru (Bond et al. 2015). But the richest locality based on the taxonomic diversity and number of primate specimens, are the middle Miocene La Venta localities in Colombia, with 11 genera, followed by the Miocene localities of Patagonia, with 8 genera (see Tejedor \& Novo 2017, and the recent discoveries by Marivaux et al. 2016).

Here we report three previously unpublished specimens of fossil primates from Patagonia, Argentina, from the paleontological collection at the Muséum national d'Histoire naturelle (MNHN.F), Paris. These are part of the Tournouër collection. André Tournouër was a geologist and explorer born in Paris in 1871. He moved to Mendoza Province, Argentina, in the 1890s, where he raised cattle. Following the advice of Albert Gaudry, a French geologist, paleontologist and by then professor at the MNHN, Tournouër made several trips between 1898 and 1904 to the Argentine Patagonia collecting fossil mammals from beds of the Casamayoran, Deseadan, Colhuehuapian, Santacrucian and Lujanian South American Land Mammal Ages (SALMAs) (Tournouër 1902, 1903a, b, 1914, 1922; Gaudry 1902a, b, c, 1904, 1906a, b, 1908; Simpson 1964, 1984; Madden \& Scarano 2010).

As a result of those expeditions, Tournouër contributed a considerable amount of Cenozoic fossils to the MNHN
(Buffetaut 2013) but the primates, although identified at the collection, were never described or published. We found only a brief comment in Gaudry (1906b: 26): "Il a inscrit sous le nom d'Homomculus une petite bête dont la tête est grande comme celle d'un Ouistiti (1). N'ayant dans nos collections que des pièces incomplètes d'Homomculidés, je ne veux pas donner une opinion personnelle. Je peux dire seulement que d'après les découvertes faites jusqu'à présent, il n'y a pas eu en Patagonie de Singes anthropomorphes".

The three previously unreported fossil primates we describe here include a partial mandible collected in 1902, here assigned to Homunculus patagonicus Ameghino, 1891, and a deciduous upper premolar and one permanent upper molar collected in 1899, here assigned to Mazzonicebus almendrae Kay, 2010. Both genera are monotypic taxa. These specimens provide new morphological information of the mandible and dentition of Homunculus Ameghino, 1891, and the first evidence of the deciduous dentition of Mazzonicebus Kay, 2010.

\section{ABBREVIATIONS}

MACN-A Museo Argentino de Ciencias Naturales "Bernardino Rivadavia", Colección Nacional Ameghino, Buenos Aires, Argentina;

MACN-PV SC Museo Argentino de Ciencias Naturales "Bernardino Rivadavia”, Buenos Aires, Santa Cruz collection;

MACN-PV CH Museo Argentino de Ciencias Naturales "Bernardino Rivadavia”, Buenos Aires, Chubut collection;

MNHN.F.SCZ Muséum national d'Histoire naturelle, Paris, Santa Cruz collection;

MNHN.F.COL Muséum national d'Histoire naturelle, Paris, Colhue Huapi collection;

MPEF-PV Museo Paleontológico "Egidio Feruglio", Paleontología de Vertebrados. Trelew, Chubut;

MPM-PV Museo Regional Provincial "Padre Manuel Jesús Molina”, Río Gallegos, Santa Cruz. 


\section{SYSTEMATIC PALEONTOLOGY}

Order PRIMATES Linnaeus, 1758

Suborder ANTHROPOIDEA Mivart, 1864

Parvorder PLATYRRHINI E. Geoffroy, 1812

Family PITHECIIDAE Mivart, 1865

Subfamily Homunculinae Ameghino, 1894

Genus Homunculus Ameghino, 1891

Homunculus patagonicus Ameghino, 1891

NEOTYPE. - MACN-A 5757; partial mandible preserving a complete and worn dentition lacking crowns of the left canine and the incisors. This is a replacement (see Tejedor \& Rosenberger 2008) for the lost holotype specimen, MACN-A 634

Geographic And STRatigraphiC PROVEnANCE. - The neotype MACN-A 5757 comes from Corriguen Aike (= Puesto Estancia La Costa), on the Atlantic coast of Santa Cruz Province between the rivers Coyle and Gallegos, Argentina. Santa Cruz Formation, late-early Miocene (Burdigalian Age), c. 17.5 to $16.7 \mathrm{Ma}$ (Tauber 1997; Fleagle et al. 2012).

NeW REFERRED MATERIAL. - MNHN.F.SCZ215 (Fig. 2A-C), partial mandible preserving the left ramus with alveoli for left i1-2, c, p2, broken alveoli of p3-4, and complete m1; alveoli for right i1-2, and broken c.

GEOGRAPHIC AND STRATIGRAPHIC PROVENANCE. - MNHN.F.SCZ215 is labeled as "Homunculus // Coyle 1902-6" (Fig. 2E). Thus, the provenance is certainly nearby the Coyle river on the Atlantic coast of Santa Cruz Province, Argentina. Santa Cruz Formation, late-early Miocene (Burdigalian Age) (see Marshall 1976; Tauber 1997; Buffetaut 2014), approximately 16.1-16.5 Ma (Fleagle et al. 2012) (Fig. 1).

\section{DESCRIPTION}

Based on comparisons, the mandible MNHN.F.SCZ215 is indistinguishable from the cast of the lost MACN-A 634, the type of Homunculus patagonicus. MACN-A 634 is strongly worn but shows several morphological similarities at the alveolar level as well as the crown outline and size of $\mathrm{m} 1$. The size and orientation of the alveoli indicate that the specimen had small roots and procumbent, staggered incisors, producing a V-shaped mandible. The small alveolus for the left canine, similar in size to the alveolus of $\mathrm{p} 2$, indicates that the canine was small, as seen in the neotype of Homunculus patagonicus (MACN-A 5757) (Tejedor \& Rosenberger 2008).

Compared to MACN-A 635, this specimen has slightly larger alveoli for the canines and a somewhat more robust mandible. Remarkably, the $\mathrm{m} 1$ of this new specimen is one of the best preserved lower molars attributed to Homunculus. Its morphology resembles MACN-A 5969b. It has two roots and the trigonid is higher than the talonid, with moderately high and sharp crests. The preprotocristid extends forward closing the trigonid mesially; the paraconid is absent, and there is an oblique cristid connecting the preparacristid. The metaconid is the highest cusp, and is situated relative to the protoconid in a more distal position. The hypoflexid appears relatively deep. It shows a tiny cuspule as seen in the m1 of MACN-A
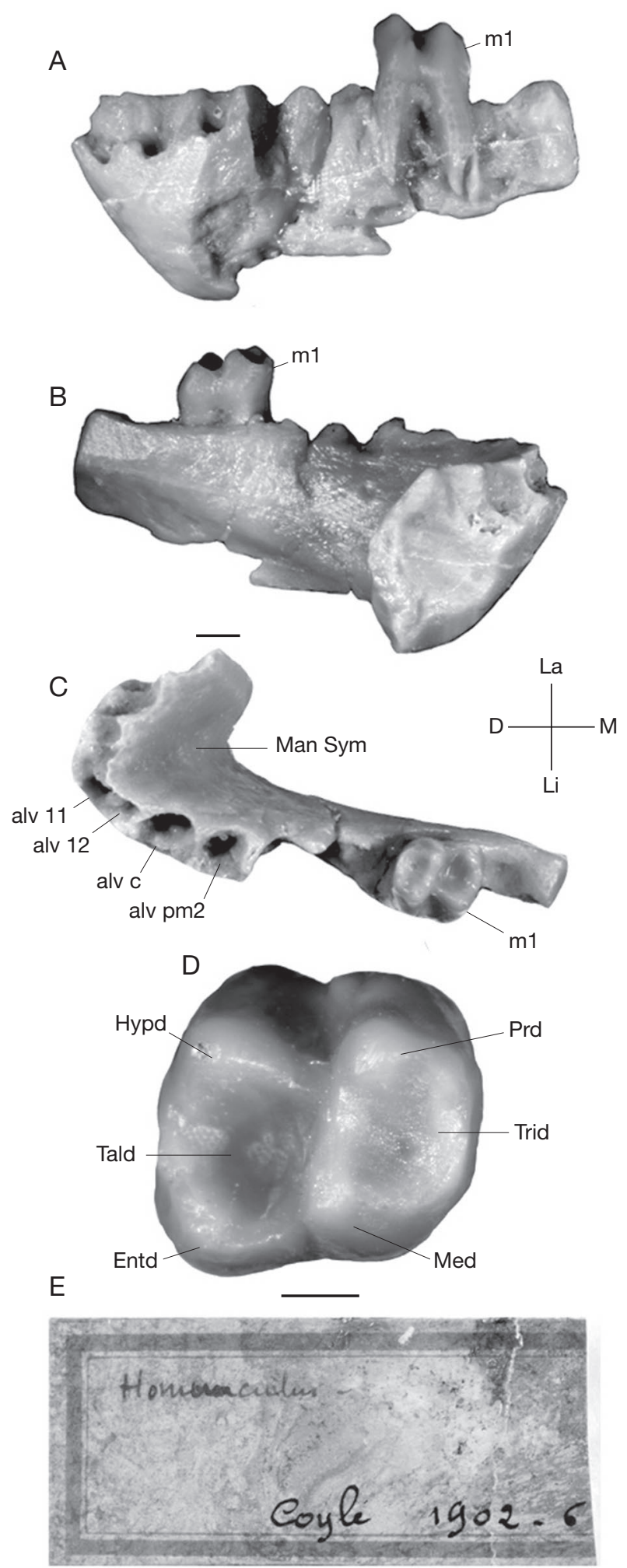

FIG. 1. - MNHN.F.SCZ215, partial mandible of Homunculus patagonicus Ameghino, 1891 with left $\mathrm{m} 1$ in lateral left $(\mathbf{A})$, lateral right (B) and dorsal (C) views; D, m2 of MNHN.F.SCZ215; E, MNHN.F.SCZ215 identification label from MNHN. Abbreviations: alv i1, first incisor alveolus; alv i2, second incisor alveolus; alv c, canine alveolus; alv pm2, second premolar alveolus; Man Sym, Mandibular symphysis; Hypd, Hypoconid; Prd, Protoconid; Trid, Trigonid basin; Med, Metaconid; Entd, Entoconido; Tald, Talonid basin. Orientation abbreviations: D, Distal; La, Labial; M, Mesial; Li, Lingual. Scale bar: $1 \mathrm{~mm}$. 

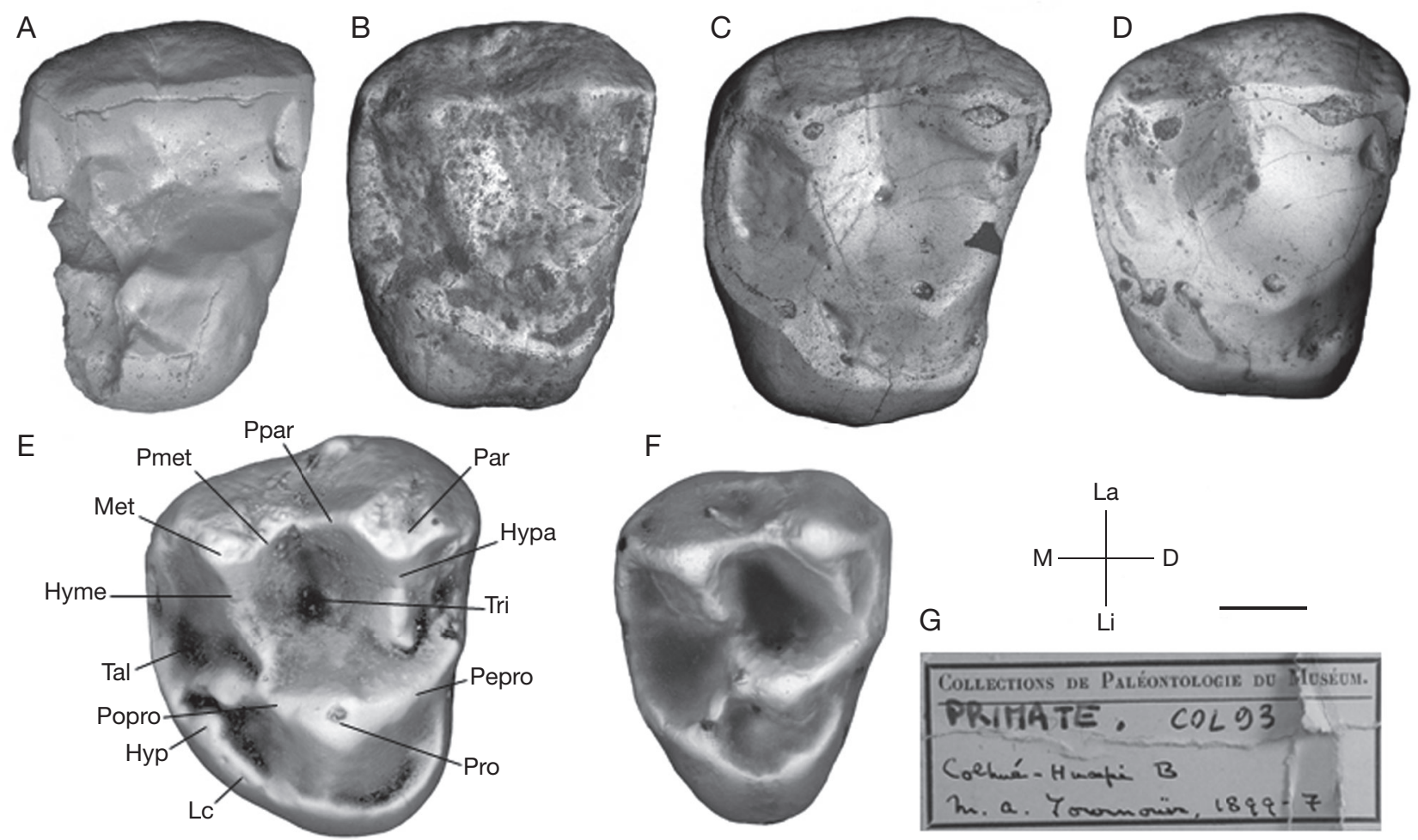

FIG. 2. - A, M2 to MPEF-PV 10970; B, MPEF-PV 5342; C, MPEF-PV 5347b; D, MPEF-PV 5699 (mirror image); E, MNHN.F.COL93b (mirror image); F, MNHN.F.COL93a (mirror image); G, MNHN.F.COL93b and MNHN.F.COL93a identification label from MNHN. Abbreviations: Hyp, Hypocone; Pro, Protocone; Tal, Talon basin; Tri, Trigon basin; Met, Metacone; Lc, Lingual cingulum; Prepro, Preprotocrista; Hypa, Hypoparacrista; Par, Paracone; Ppar, Postparacrista; Pmet, Premetacrista; Hyme, Hypometacrista; Popro, Postprotocrista. Orientation abbreviations: D, distal; La, labial; M, mesial; Li, lingual. Scale bar: 1 mm.

5969b. The molar has a long cristid obliqua reaching the trigonid wall lingual to the protoconid, while the hypoconid is displaced labially. The entoconid is lower than the hypoconid, with a long entocristid. The talonid basin is relatively wide and deep, showing an incipient and centrally placed hypoconulid (Fig. 2).

\section{Subfamily PithecinnAe Mivart, 1865}

\section{Mazzonicebus almendrae Kay, 2010}

HOLOTYPE. - MPEF-PV 6752, partial mandible preserving the symphysis and left 11-M1.

GEOGRAPHIC AND STRATIGRAPHIC PROVENANCE. — Colhue-Huapi, West locality, Gran Barranca, Chubut Province, Argentina. The material was collected in the Lower Fossil Zone, Colhue-Huapi Member, Sarmiento Formation, dated between 20.0 and 20.2 Ma (Ré et al. 2010).

New ReferRed MATERIAL. - MNHN.F.COL93a, left dP4; MNHN.F.COL93b, left M2.

GEOGRAPHIC AND STRATIGRAPHIC PROVENANCE. - The specimen label reads (Fig. 3G): "Primate, col 93 // Colhué Huapi B // M.A. Tournouër, 1899-7”. Both specimens were found in the box with the same label. Thus, the provenance is certainly Gran Barranca in Chubut Province, Argentina. The Colhue-Huapi Member of the Sarmiento Formation is, early Miocene (Burdigalian Age) (see Simpson 1964; Madden \& Scarano 2010 and references therein), approximately 20.0-20.2 Ma (Ré et al. 2010).

\section{DESCRIPTION}

MNHN.F.COL93a (Fig. 3F), is a three rooted dP4 with unworn paracone, metacone placed more labially, and a welldeveloped protocone, as well as a hypocone placed on the distolingual cingulum. It has a morphological pattern similar to that known for the upper molars of Mazzonicebus almendrae. This tooth is smaller than M1-2 although larger than M3. It is similar in size and general aspect to the M2 of Soriacebus ameghinorum Fleagle, Powers, Conroy \& Watters, 1987, as in MACN-PV SC67, differing in that MNHN.F.COL93a has a more lingually expanded lingual cingulum which produces a triangular crown outline. One important difference is that the talon basin is distally expanded in MACN-PV SC67.

The upper deciduous dentition is not known for either $\mathrm{Maz}$ zonicebus or Soriacebus Fleagle, Powers, Conroy \& Watters, 1987 and, in general, the deciduous dentition is scarcely known for any fossil primates from Patagonia. A dP4 assigned to Dolichocebus gaimanensis Kraglievich, 1951 (MACN-PV CH1011), provides a general morphological model of a deciduous tooth for the Patagonian platyrrhines. Both these teeth have similar sub-triangular outlines due to the narrow lingual expansion of the lingual cingulum. This combination of features is usually seen in the $\mathrm{dP} 4 \mathrm{~s}$ of Carlocebus carmenensis Fleagle, 1990 (e.g. MACN-PV SC113), and in the $\mathrm{dP} 4$ present in the juvenile cranium of Homunculus patagonicus, MPM-PV 3505 (Perry et al. 2014). MACN-PV CH1011 shows the strong hypometacrista connected to the postprotocrista, unlike that weakly developed, without connection to the postprotocrista, exhibited by MNHN.F.COL93a. In addition, 
TABLE 1. - Size differences between Homunculus patagonicus Ameghino, 1891 and Mazzonicebus almendrae Kay, 2010.

\begin{tabular}{lll}
\hline Specimen & MD (mm) & BL (mm) \\
\hline Homunculus patagonicus & & \\
MNHN.F.SCZ215 (m1) & 4.48 & 3.91 \\
MACN-A 5757 (right m1) & 4.68 & 4.73 \\
MACN-A 5969b (m1) & 4.5 & 3.83 \\
\hline Mazzonicebus almendrae & & \\
MNHN.F.COL93a (dP4) & 3.38 & 3.9 \\
MNHN.F.COL93b (M2) & 3.96 & 4.32 \\
MEPEF-PV 5486 (M2) & 3.52 & 5.11 \\
MEPEF-PV 5342 (M2) & 3.86 & 4.68 \\
MEPEF-PV 5347 (M2) & 4.02 & 4.89 \\
MEPEF-PV 5699 (M2) & 4.11 & 4.96 \\
\hline
\end{tabular}

they differ in that the prehypocrista in MNHN.F.COL93a is oriented more lingually with respect to the distolingual orientation observed in MACN-PV CH1011.

Regarding the remaining tooth reported here, the comparisons between MNHN.F.COL93b and the upper molars assigned to Mazzonicebus almendrae indicate that the size (Table 1) and morphology of the M2 match well with the M2s MPEF-PV 5699, MPM-PV 5342, and MPEF-PV 5347b; however, the lingual cingulum is less expanded anterolingually, and the molar has a very small hypocone. Its occlusal outline is more rounded instead of the nearly trapezoidal shape in Mazzonicebus. An unusual condition is seen in the hypocone development in MNHN.F.COL93b, which is divided in two tiny cusps separated by a sulcus. The metacone is aligned somewhat more lingually with respect to the paracone, and the postparacrista descends to join the premetacrista in a middle position. The protocone is well developed and has a preprotocrista reaching a shallow mesial fovea. The molar has a distinct hypoparacrista descending from the paracone, and a hypometacrista that reaches the postprotocrista at the intersection of the prehypocrista.

Other morphological characters of the M1 are shared with Mazzonicebus. For example, the cusps are moderately developed, with similar outline and depth of the trigon, a strong preprotocristid without a paraconule, talon distally expanded, and a mesial fovea is present.

On the other hand, MNHN.F.COL93b (Fig. 3E) was also compared with Soriacebus ameghinorum, especially the M1 of MACN-PV SC67, a maxillary fragment with well preserved M1-2. It is similar in size, has a strong preprotocrista, with the postprotocrista distally oriented to reach the hypocone, and a mesial fovea is present. MNHN.F.COL93b has a more rounded outline, but is also buccolingually shorter, and the talon is not so expanded distally as in MACN-PV SC67. The lingual cingulum is definitely more developed in MACN-PV SC67, with a strong anterolingual extension, and the hypocone is also more developed. These are the two most distinctive characters separating MNHN.F.COL93b and Soriacebus. In addition, MACN-PV SC67 has a more expanded labial side in M1-2.

Although Mazzonicebus and Soriacebus are closely related (see Tejedor \& Novo 2017), these comparisons reinforce the idea that MNHN.F.COL93b is an M2 of Mazzonicebus and not an M1 of Soriacebus (see size differences in Table 1).

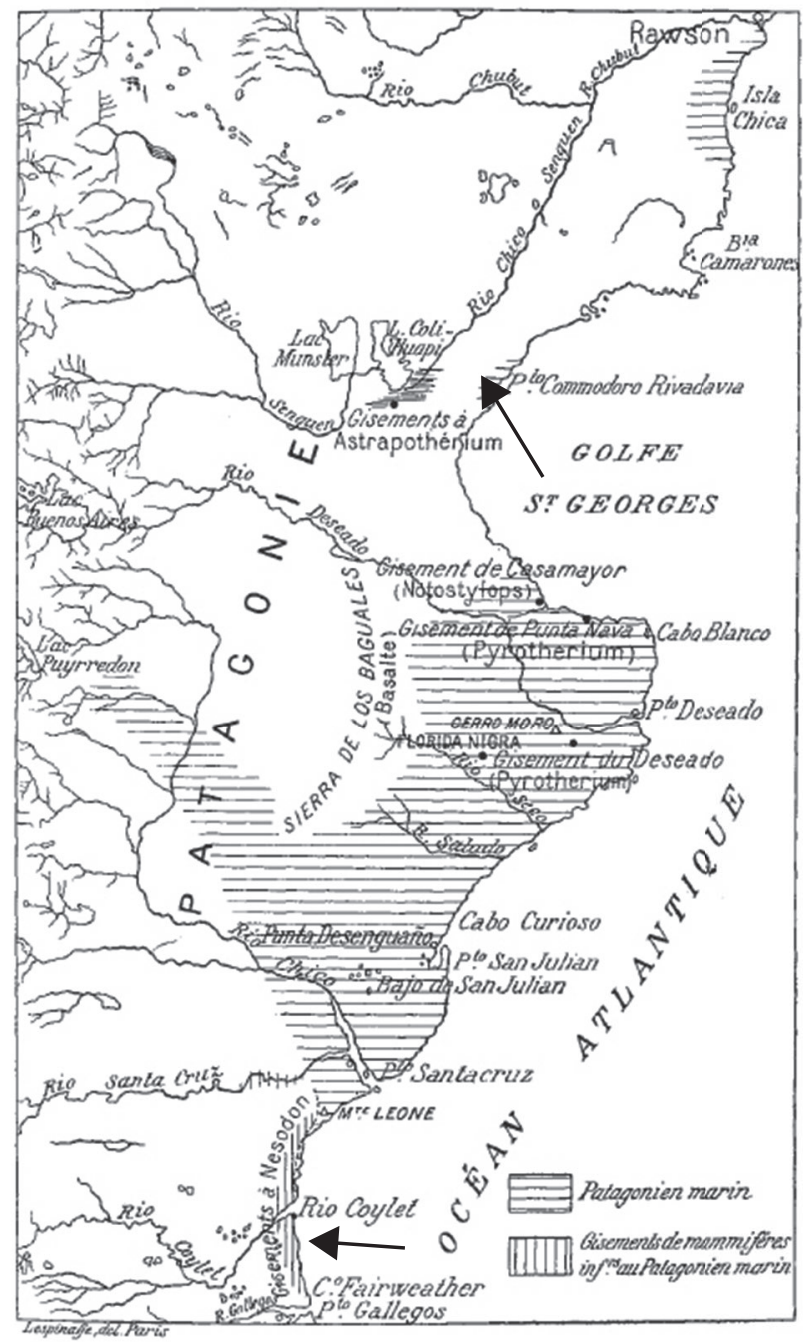

FIG. 3. - Map of central and eastern Patagonia modified from Tournouër (1922). Arrows pointing "Coli Huapí" and Río Coyle.

\section{DISCUSSION AND CONCLUSIONS}

\section{NEW SPECIMEN OF HOMUNCULUS PATAGONICUS}

The comparative morphological study mentioned above allows us to assign the previously undescribed mandible MNHN.F.SCZ215 to Homunculus patagonicus. The dental morphology of Homunculus resembles the extant pitheciid Callicebus, while the mandible is closer to the living Aotus (Tejedor 1997, 2000; Tejedor \& Rosenberger 2008). However, in alternative phylogenetic views, Homunculus is positioned both as part of a stem platyrrhine group within the Patagonian primates (excepting Proteropithecia Kay, Johnson \& Meldrum, 1998, Chilecebus Flynn, Wyss, Charrier \& Swisher, 1995 and Branisella Hoffstetter, 1969 (Kay 2015), or as part of the crown Platyrrhini in the subfamily Homunculinae among the pitheciids (Rosenberger et al. 1990; Tejedor 2000; Tejedor \& Rosenberger 2008; Bond et al. 2015; Novo 2015; Tejedor \& Novo 2017). The latter hypothesis is supported here.

Although the fossil record of Homunculus is represented by approximately forty specimens, including skulls, mandibular 
fragments, isolated teeth and postcranial material (Ameghino 1891; Bluntschli 1931; Tauber 1991; Tejedor 2000; Tejedor \& Rosenberger 2008; Perry et al. 2010; Kay et al. 2012; Perry et al. 2014; Novo 2015), the controversies around the phylogenetic relationships of the genus remain under debate.

The specimen reported here provides valuable information about the mandibular morphology and possible generic variability (or sexual dimorphism? e.g., the extreme size difference of the alveolus for the canine with respect to MACN-A 635), and exhibits one of the best preserved lower molars known for the genus.

\section{THE NEW SPECIMENS OF MAZZONICEBUS ALMENDRAE}

The specimens MNHN.F.COL93a and COL93b, here attributed to Mazzonicebus almendrae, have been labeled as collected in the year 1899, according to the MNHN information. Thus, they could have been the second record of pre-Pleistocene fossil primates in Argentina after Homunculus patagonicus. Instead, the genus Mazzonicebus was not described until more than 100 years later (Kay 2010).

When Kay (2010) described Mazzonicebus, from the ColhueHuapi member, Sarmiento Formation at Gran Barranca, he included new specimens as well as others previously reported and housed at the Museo de La Plata. One of them is a symphysis preserving a right p4, MLP 69-III-12-2, collected at Gran Barranca by Robert Goulet in 1967; the specimen was formerly referred to cf. Homunculus patagonicus by Hershkovitz (1981), and then to Soriacebus cf. ameghinorum by Fleagle (1990). Kay (2010) noted that MLP 69-III-12-2 was the first record of primates coming from Gran Barranca, adding that, even with the efforts of renowned field expeditions since the times of the Ameghino brothers, and later by the George G. Simpsons's expeditions to Patagonia in the 1930s, no primates were found by then. Incidentally, the new material described here was collected well before 1967, in the year of 1899, as indicated in the label.

André Tournouër was a colleague, perhaps a friend and competitor of the Ameghino brothers, and apparently there was controversy about who was the actual discoverer of Gran Barranca (Madden \& Scarano 2010). According to Tournouër's publications about his travels to Patagonia, and later investigations about the origin of the fossils from Tournouër collection, the specimens that are labeled Colhue-Huapi ("Coli-Huapi”" as he spelled it, Tournouër 1902, 1903a, b) would all have come from the Colhuehuapian levels at Gran Barranca (Simpson 1964; Madden \& Scarano 2010).

Mazzonicebus is closely related to Soriacebus, from the Pinturas Formation, even according to the two different views on their higher-phylogeney interrelationships, as explained above for the case of Homunculus and other Patagonian primates. In our view, Soriacebus and Mazzonicebus are extinct members of the Pitheciidae, and part of the subfamily Pitheciinae (Rosenberger et al. 2009; Tejedor 2013; Tejedor \& Novo 2017; contra Kay 2015).

In sum, the new specimens of Mazzonicebus reported here provide the first evidence of deciduous dentition for the genus, as well as some historic evidence about the ancient discoveries of fossil platyrrhine primates in South America.

\section{Acknowledgements}

We are grateful to the Muséum national d'Histoire naturelle, Paris and to Guillaume Billet for authorizing the access to the Tournouër collection and for providing the cast of the unpublised specimens. To the Museo Paleontológico "Egidio Feruglio" and especially to Eduardo Ruigomez for authorizing the access to Mazzonicebus specimens. To ALUAR (Aluminios Argentinos, Puerto Madryn) and J. Groizard for providing access to the Scanning Electron Microscope to take the pictures. We also thank the A. Rosenberger and J. Fleagle for their helpful comments. This work was partially funded by CONICET and the projects PICT 2015-2036 to NMN y PICT 2014-1818 to MFT.

\section{REFERENCES}

AMEGHINO F. 1891. — Los monos fósiles del Eoceno de la República Argentina. Revista Argentina de Historia Natural 1: 383-397.

BLUNTSCHLI H. 1931. - Homunculus patagonicus und die ihm zugereihten fossilfunde aus den Santa Cruz Schichten Patagoniens. Eine morphologische revision an hand der originaltücke in der sammlung Ameghino zu La Plata. Morphologisches Jabrbuch LXVII (Goppert-Festschrift II): 811-892, figs 1-47.

Bond M., Tejedor M. F., Campbell K., Chornogubsky L., Novo N. M. \& GoIN F. J. 2015. - Eocene primates of South America and the African origin of New World Monkeys. Nature 520: 538-541. https://doi.org/10.1038/nature14120

BuFFETAUT E. 2013. - André Tournouër (1871-1929), membre fondateur de la Société linnéenne de la Seine Maritime et explorateur de la Patagonie. Bulletin mensuel de la Société linnéenne de la Seine Maritime, Bulletin spécial 100e anniversaire 1913-2013: 21, 22.

Buffetaut E. 2014. - Tertiary ground birds from Patagonia (Argentina) in the Tournouër collection of the Muséum national d'Histoire naturelle, Paris. Bulletin de la Société géologique de France 185 (3): 207-214. https://doi.org/10.2113/gssgfbull.185.3.207

Fleagle J. G. 1990. - New fossil platyrrhines from the Pinturas Formation, Southern Argentina. Journal of Human Evolution 19: 61-85. https://doi.org/10.1016/0047-2484(90)90012-Z

Fleagle J. G., Perkins M. E., Heizler M. T., Nash B., Bown T. M., Tauber A. A., Dozo M. T. \& Tejedor M. F. 2012. Absolute and relative ages of fossil localities in the Santa Cruz and Pinturas Formations, in VizCAÍNO S. F., KAY R. F. \& BARGO M. S. (eds), Early Miocene Paleobiology in Patagonia: High-Latitude Paleocommunities of the Santa Cruz Formation. Cambridge University Press, Cambridge: 41-58. https://doi.org/10.1017/ CBO9780511667381.004

Gaudry A. 1902a. - Mission de M. André Tournouër en Patagonie. Bulletin de la Société géologique de France 4 (2): 345. https:// biodiversitylibrary.org/page/30750126

GAUDRY A. 1902b. - Recherches paléontologiques de M. André Tournouër en Patagonie. Bulletin de la Société géologique de France 4 (2): 378. https://biodiversitylibrary.org/page/30750175

GAUDRY A. 1902c. - Recherches paléontologiques de M. André Tournouër en Patagonie. Bulletin de la Société d'Histoire naturelle d'Autun 15: 117-123. https://gallica.bnf.fr/ark:/12148/ bpt6k121911f/f653.item

GAUdrY A. 1904. - Fossiles de Patagonie. Dentition de quelques mammiferes. Mémoires de la Société géologique de France, Paléontologie 31: 5-27. https://biodiversitylibrary.org/page/51880156

GAUDRY A. 1906a. - Fossiles de Patagonie. Les attitudes de quelques animaux. Annales de Paléontologie 1: 1-42.

GAUdrY A. 1906b. - Fossiles de Patagonie. Étude sur une portion du monde Antartique. Annales de Paléontologie 1 (3): 101-143.

GAudry A. 1908. - Fossiles de Patagonie. De l'économie dans la nature. Annales de Paléontologie 3: 1-7. 
Gaudry A. 1909. - Fossiles de Patagonie. Le Pyrotherium. Annales de Paléontologie 4: 1-28.

HeRSHKOVITZ P. 1981. - Comparative anatomy of platyrrhine mandibular cheek teeth dpm4, pm4, m1, with particular reference to those of Homunculus (Cebidae), and comments on platyrrhine origins. Folia Primatologica 35: 179-217. https:// doi.org/10.1159/000155972

KAY R. F. 2010. - A new primate from the early Miocene of Gran Barranca, Chubut Province, Argentina: Paleoecological implications, in Madden R. H., Carlini A. A., Vucetich M. G. \& KAY R. F. (eds), The Paleontology of Gran Barranca: Evolution and Environmental Change through the Middle Cenozoic of Patagonia. Cambridge University Press, Cambridge: 220-240.

KAY R. F. 2015. - Biogeography in deep time - What do phylogenetics, geology, and paleoclimate tell us about early platyrrhine evolution? Molecular Phylogenetic Evolution 82 (B): 358-374. https://doi.org/10.1016/j.ympev.2013.12.002

KaY R. F., Vizcaíno S. F. \& BARGO M. S. 2012. - A review of the paleoenvironment and paleoecology of the Miocene Santa Cruz Formation, in Vizcaíno S. F., KaY R. F. \& Bargo M. S. (eds), Early Miocene Paleobiology in Patagonia: High-Latitude Paleocommunities of the Santa Cruz Formation. Cambridge University Press, Cambridge: 331-364. https://doi.org/10.1017/ CBO9780511667381.018

MADDEN R. H. \& SCARANO A. C. 2010. — Notes toward a history of vertebrate paleontology at Gran Barranca, in MADDEN R.H., Carlini A. A., Vucetich M. G. \& Kay R. F. (eds), The Paleontology of Gran Barranca: Evolution and Environmental Change through the Middle Cenozoic of Patagonia. Cambridge University Press, Cambridge: 1-15.

Marivaux L., Adnet S., Altamirano-Sierra A. J., Pujos F., Ramdarshan A., Salas-Gismondi R., Tejada-Lara J. V. \& ANTOINE P. O. 2016. - Dental remains of cebid platyrrhines from the earliest late Miocene of Western Amazonia, Peru: Macroevolutionary implications on the extant capuchin and marmoset lineages. American Journal of Physical Anthropology 161 (3): 478-493. https://doi.org/10.1002/ajpa.23052

Marshall L. G. 1976. — Fossil Localities for Santacrucian (Early Miocene) Mammals, Santa Cruz Province, Southern Patagonia, Argentina. Journal of Paleontology 50 (6): 1129-1142. https:// www.jstor.org/stable/1303553

Morrone J. J. 2006. - Biogeographic areas and transition zones of Latin America and the Caribbean islands based on panbiogeographic and cladistic analyses of the entomofauna. Annual Review of Entomology 51: 467-494. https://doi.org/10.1146/ annurev.ento.50.071803.130447

Novo N. M. 2015. - Sistemática y evolución de los primates platirrinos: la diversidad del Mioceno patagónico y su integración neotropical. PhD thesis (unpublished), Universidad Nacional del Comahue, Bariloche, Argentina.

Perry J. M. G., Kay R. F., Vizcaino S. F. \& Bargo M. S. 2010. Tooth root size, chewing muscle leverage, and the biology of Homunculus patagonicus (Primates) from the late early Miocene of Patagonia. Ameghiniana 47 (3): 355-371. https://doi. org/10.5710/AMGH.v47i3.9

Perry J. M. G., Kay R. F., Vizcaino S. F. \& Bargo M. S. 2014. Oldest known cranium of a juvenile New World monkey (Early Miocene, Patagonia, Argentina): Implications for the taxonomy and the molar eruption pattern of early platyrrhines. Journal of Human Evolution 74: 67-81. https://doi.org/10.1016/j.jhevol.2014.03.009
Ré G., Bellosi E. S., Heizler M., Vilas J., Madden R., Carlini A., KAY R. \& VuCETICH M. G. 2010. - Geochronology for the Sarmiento Formation at Gran Barranca, in MADDEN R. H., Carlini A. A., Vucetich M. G. \& Kay R. F. (eds), The Paleontology of Gran Barranca: Evolution and Environmental Change through the Middle Cenozoic of Patagonia. Cambridge University Press, Cambridge: 46-59.

Rosenberger A. L., Setoguchi T. \& Shigehara N. 1990. - The fossil record of callitrichine primates. Journal of Human Evolution 19: 209-236. https://doi.org/10.1016/0047-2484(90)90017-6

Rosenberger A. L., Tejedor M. F., Cooke S. \& Pekar S. 2009. - Platyrrhine ecophylogenetics in space and time, in Garber P., Estrada A., Bicca-Marquez J. \& Strier K. (eds), South American Primates: Testing new Theories in the Study of Primate Behavior, Ecology, and Conservation. Developments in Primatology: progress and prospects (Series editor: Russell H. Tuttle). Springer Press, New York: 69-113. https://doi. org/10.1007/978-0-387-78705-3

SiMPSON G. G. 1964. - Los mamíferos Casamayorenses de la colección Tournouër. Revista del Museo Argentino de Ciencias Naturales "Bernardino Rivadavia" 1: 1-21.

SimPSON G. G. 1984. — Discoverers of the Lost World. Yale University Press, New Haven and London, 224 p.

Tauber A. A. 1991. - Homunculus patagonicus Ameghino 1891 (Primates, Ceboidea), Mioceno temprano de la costa atlántica austral, Provincia de Santa Cruz, República Argentina. Academia Nacional de Ciencias 82: 1-32.

Tauber A. A. 1997. - Bioestratigrafía de la Formación Santa Cruz (Mioceno Inferior) en el extremo sudeste de la Patagonia. Ameghiniana 34 (4): 413-426.

Tejedor M. F. 1997. - La dentición de Callicebus y el morfotipo ancestral de los platirrinos. Neotropical Primates 5: 43-46.

Tejedor M. F. 2000. — Los Platyrrhini fósiles de la Patagonia (Primates, Anthropoidea). Sistemática, filogenia e inferencias paleoambientales. PhD thesis (unpublished), Facultad de Ciencias Naturales y Museo, Universidad Nacional de la Plata.

TEJEDOR M. F. 2013. - Sistemática, evolución y paleobiogeografía de los primates Platyrrhini. Revista del Museo de La Plata 20: 20-39. http://hdl.handle.net/11336/1324

Tejedor M. F. \& Rosenberger A. L. 2008. - A neotype for Homunculus patagonicus Ameghino, 1891, and a new interpretation of the taxon. Paleoanthropology 2008: 68-82.

Tejedor M. F. \& Novo N. M. 2017. - Platyrrhine evolution and paleobiogeography revisited, in KOWALEWSKI M. \& OKLANDER L. (eds), La primatología en Argentina I. Mendoza, Argentina, Editorial SAREM: 25-48.

TOURNOUËR A. 1902. - Recherches paléontologiques en Patagonie. Comptes Rendus des Séances de l'Académie des Sciences 135: 540543. https://gallica.bnf.fr/ark:/12148/bpt6k64435428/f546.item

TOURnOUËr A. 1903a. - Coupes des terrains tertiaires de la Patagonie. Comptes Rendus des Séances de l'Académie des Sciences 1903: 348-349.

TOURNOUËR A. 1903b. - Note sur la géologie et la paléontologie de la Patagonie. Bulletin de la Société géologique de France 4 (3): 463-473. https://biodiversitylibrary.org/page/30841985

TOURnOUËR A. 1914. - Notes sur la Patagonie. Bulletin mensuel de la Société linnéenne de la Seine Maritime 2: 10-12.

TOURNOUËR A. 1922. - Recherches paléontologiques en Patagonie. Bulletin mensuel de la Société linnéenne de la Seine Maritime 8-9: 236-240. 